\title{
Bilateral striopallidodentate calcinosis
}

INSERM

\section{Source}

INSERM. (1999). Orphanet: an online rare disease and orphan drug data base. Bilateral striopallidodentate calcinosis. ORPHA:1980

Bilateral striopallidodentate calcinosis (BSPDC, also erroneously called Fahr disease) is characterized by the accumulation of calcium deposits in different brain regions, particularly the basal gang lia and dentate nucleus, and is often associated with neurodegeneration. 